\title{
Examination of the Relationship between Financial Market Liberalisation and the Failures of Small and Medium Sized Enterprises in Nigeria
}

\author{
Obokoh, Lawrence Ogechukwu (ACA) \\ Department of Management and Accounting, Obafemi Awolowo University, Ile-Ife, Nigeria \\ Tel: 234-703-777-1207 E-mail: Lechukwu2001@yahoo.com \\ Asaolu, Taiwo O. (FCA) \\ Department of Management and Accounting, Obafemi Awolowo University, Ile-Ife, Nigeria \\ E-mail: twasaolu@yahoo.co.uk
}

Received: July 26, 2011

doi:10.5539/ibr.v5n1p182

\author{
Accepted: September 24, 2011 \\ Published: January 1, 2012 \\ URL: http://dx.doi.org/10.5539/ibr.v5n1p182
}

\begin{abstract}
The paper presents the methodological process applied in arriving at the result of the impact of economic liberalisation on the access to finance by SMEs and how the policy has contributed to the survival or otherwise of manufacturing SMEs following the implementation in 1992. The policy was envisaged to encourage the inflow of investible funds into Nigeria for greater SMEs access to funds by the governments' deregulation of interest rates, exchange rates and the licensing of new banks to stimulate competition for the supply of investible funds. The extent to which the policy has achieved its objectives still remains a puzzle.

However, the application of return on investment (ROI) model on SMEs transaction records reveals that financial market liberalisation partly contributed to the failures of most manufacturing SMEs in Nigeria contrary to the policy objective of improved SMEs opportunities and access to finance. Instead of the competitive free-market rates to attract funds for investment, it became an obstacle that partly hindered the survival of manufacturing SMEs. The result of the study is further strengthened by the outcome of the global financial crisis and the call for regulation of the financial markets.
\end{abstract}

Keywords: Financial markets, Liberalisation, SMEs, Free-market rate, Manufacturing

\section{Introduction}

This paper presents the methodological process followed to arrive at the findings of a longitudinal study of the impact of economic liberalisation on small and medium sized enterprises (SMEs) development in Nigeria. In the specific instance, the impact of financial market liberalisation on the access to finance as well as the survival chances of manufacturing SMEs following the liberalisation of the financial market in 1992. The liberalisation process initially started with the adoption of structural adjustment programme (SAP). The adoption of SAP was as a result of the fall in revenue due to the glut in the international market for primary products which subsequently led to the fall in the price of primary products (Akinlo, 1996; Ajibefun and Daramola, 2003).

This resulted in decreased revenue earnings for the Nigerian government because of its dependence on primary products as the major foreign exchange source. The decrease in revenue resulted in the balance of payment crisis that exposed the deficiencies of the manufacturing sector to support the domestic needs of finished goods (Ikhide and Alawode, 2001; Olukoshi, 1996). This deficiencies/structural weakness in the manufacturing sector prompted the shift from the import substitution industrialisation (ISI) strategy adopted at independence in 1960 to export promotion industrialisation strategy. In this strategy, the private sector (SMEs) was proposed to play a critical role while the government acts as facilitator of economic activities (Ikpeze, et al, 2004).

To achieve this, the policy excised government of its powers/roles in the active participation of economic activities. This prompted the commercialisation and privatisation of all public parastatals, removal of subsidies on petroleum products and cuts in public service budgets to make more funds available to the government (Okome, 1999; Nwankwo and Richards, 2001; Ajibefun and Daramola, 2003). The commercialisation and privatisation exercise in 
addition to cuts in public service budgets translated to the reduction in the budgets for the provision and maintenance of public infrastructure (Lee and Anas, 1992; Adenikinju, 2005).

Further steps taken to restructure the economy to ensure efficiency as recommended by the IMF/World Bank in the reform policy were the liberalisation of trade and the financial markets. The liberalisation of trade was expected to ease the importation of raw materials to boost local production, remove bottlenecks in the importation of finished goods that would provide needed competition in the domestic goods market (Akinlo, 1996). The liberalisation of the financial market also saw the deregulation of interest rates, exchange rates and the removal of restriction on the registration of new financial institutions (Ikhide and Alawode, 2001). The reason was to allow for free entry of new financial institutions into the financial market that would engender competition and make it possible for the introduction of new financial products (Ebhodaghe, 1996; Siddiki, 2000; Obadan, 2006, Hübler, et al, 2008). Furthermore, it was expected to encourage the inflow of investible funds into Nigeria for greater SMEs access to formal sector funds which was not easily accessible prior to liberalisation (Akinlo and Odusola, 2003).

\section{The Nigerian Economy and Manufacturing SMEs}

SMEs especially those in the manufacturing sector are regarded as the engine of economic growth in all economies of the world due to their undisputed contributions towards sustainable economic development through job creation and poverty alleviation (Udechukwu, 2003; Amin and Banerjee, 2007). SMEs utilizes local raw materials at the same time provide markets for raw materials to the industrial sector and serves as training ground for local entrepreneurs (Musa and Danjuma, 2007, Obokoh, 2008a). Due to the small size of SMEs, they are more flexible and easily adaptable to market/ environmental changes within a short term in their area of specialisation compared to large firms (Berry, 2002). The same small size advantage also constitutes obstacle to their accessibility to formal sector finance for their operations and expansion (Mambula, 2002; Madill et al, 2006).

This lack of access to formal sector finance tends to undermine their operations and affect their ability to contribute meaningfully to economic growth in recent times (Kyaruzi, 2006). Consequently, most governments in SSA especially Nigeria now recognises the need to provide enabling business environment that would make financial products accessible to SMEs through the liberalisation of financial market (Owualah and Obokoh, 2008). Still, how the policy measures have served and/or undermined SMEs, fiscal and monetary development, the general economic growth and development in Africa, Nigeria in particular is still heavily contested as a result of the mixed reports of the policy (Sachs and Warner, 1995; Rodríguez and Rodrik, 2000; Ikhide \& Alawode, 2001; Noorbakhsh and Paloni, 2001; Prasad, et al, 2003; Stiglitz, et al, 2006). The mixed reports is based on the different methodologies applied in the determination of the impact of liberalisation on different economic variables (Rodríguez and Rodrik, 2000; Winters, 2004).

This then necessitates a re-visit and the need to take a critical and more nuanced look at how financial market liberalisation is affecting SMEs, for good or bad. The paper believes that, it is easier to gain a deeper and more robust insight into the dynamics of economic and market relationship from SMEs, and how this, in turn, implicates the Nigerian economy from below. A further reason why the impact of financial market liberallisation on SMEs is of urgent interest is that it impinges, quite significantly, on the informal sector in Nigeria and other countries in Sub-Saharan Africa.

In the light of these backgrounds, therefore, how might we understand the implications of the policy in Nigeria, and elsewhere across Africa using a different methodological approach? How has the implementation of the policy affected the survival of SMEs and the informal sector generally? If indeed financial market liberalisation policy portends adverse effects for SMEs, as witnessed, for instance, in their poor performances and high mortality rates in recent times? How is this, in turn, responsible for some of the challenges facing SMEs, especially in terms of securing funds for their productive?

To answer these questions, the study applied mixed methods of data collection and analysis that tapped on the strengths of both quantitative and qualitative methods, besides utilizing SPSS version 16, spread sheets and content analysis to analyse the data for the study. So the aim of this paper is partly to present the methodological approach followed in the determination of whether the financial market liberalisation in Nigeria has any link with the failures/ poor performances of manufacturing SMEs and the high mortality rates associated to SMEs after the implementation of the policy. The study was carried out in Lagos state of Nigeria because the state is the industrial hub of Nigeria with the highest concentration of SMEs and covers the period 1980 to 2006.

\section{Review of Related Literature}

The liberalisation policy in Nigeria is based on the McKinnon \& Shaw (1973) theory that financial market liberalisation enables efficient allocation of scarce capital to the benefits of the rest of the economy if the 
government allow deposit rates of interest to be the competitive free-market rates. The deregulation of interest rate was aimed at making market forces determine the market rate of interest because it was postulated that markets function more efficiently without government intervention (McKinnon, 1973, Shaw, 1973). This was expected to improve the mobilisation of funds within the domestic informal sector and attract new investible funds from abroad due to the ensuring high interest rates of deregulation. The philosophy then was that, with the mobilisation of more funds from within and abroad, the saturation of the financial market with investible funds would eventually force interest rates down and make funds accessible to both local investors-SMEs and large businesses (Fry, 1988; Henry, 2003).

This has been argued in the literature as unworkable on the grounds that financial market is not like the goods market where excess supply over demand forces down prices (Stiglitz, 2000). The high interest rates will only attract speculative money from abroad and cause distress in businesses that would lead to economic crisis when the money that rushed into the country as a result of high interest rates rushes out of the economy with the slightest sign of crisis (van Wijnbergen, 1985; Stiglitz, 2004). And that government intervention is necessary because of the pervasive market failures in the financial market and the need to protect the market from particularistic interests (Stigligz, 1998; Zhang, 2006).

Van Wijnbergen (1982) and Taylor (1983) noted that the increase in the total real supply of credit depends on higher deposit rates, the required reserve ratio and on whether the increased holdings of real money balances come mainly from direct lending in the curb market. And as the deposit rate of interest increases, there is the willingness and high propensity for people to deposit their money and these reduces demand for currency and curb market loans. If substitution of deposits for currency holdings is less important than substitution of deposits for curb market loans, then the total supply of working capital will fall and the curb market interest rate will rise. Taylor (1983) and Van Wijnbergen (1982) concluded that financial liberalization is likely to reduce the rate of economic growth by reducing the total real supply of credit available to business firms in real life situations.

Reports have it that certain countries, especially in Asia experienced higher savings and investments after the liberalization of the financial sector which encouraged high interest rates (Khatkhate, 1988), but other studies report failures for some economies that undertook financial liberalization (Larrain, 1989; Hellmann, Murdock and Stiglitz, 2000). Those countries in the later category suffered considerable macroeconomic instability, massive capital flight and widespread bank failures following financial liberalization (Hellmann et al, 2000; Ikhide and Alawode, 2001; Stiglitz, 2000, 2004).

Stiglitz and Weiss (1981) also observed that high interest rate increases the risk of lending to firms. According to Stiglitz (2002), in a country where many firms are highly leveraged, high interest rates do not only weaken the banking system and induce corporate distress; they reduce the ability and willingness of lenders/ financial institutions to lend. Mussa (2000) asserted that financial liberalization had significant adverse effects on less developed countries that were not adequately prepared for it. This is in terms of proper sequencing and setting up of economic structures upon which the policy can function effectively (Mailafia, 2006; Bello, 2007).

Some of the pre-conditions that were supposed to be met such as standard fiscal and monetary policies that should ensure low fiscal deficits and inflation rates; stable and competitive exchange rates with sufficient foreign exchange reserves; a solid financial system supported by effective regulatory and supervisory mechanism were not in place before the implementation of the policy (Obadan, 2006; Emeseh, et al, 2010). In fact the Nigerian government methodology of the economic reform according to Ayadi and Hyman (2006) took a sudden approach because so many economic policy changes were undertaken within a short time. The pre-conditions were even not achievable at the time because Nigeria was experiencing adverse balance of payment crisis when she liberalised her capital account (Obokoh, 2008b).

Furthermore, to facilitate the liberalised trade and capital account convertibility, the government also deregulated the exchange rates to make the naira float according to the dictates of market forces (Akinlo, 1996; Schneider, 2000). The reason was to depreciate the 'over valued' naira to its appropriate value that would make imports more expensive. This was envisaged would encourage local production and consumption of made in Nigeria products thereby stimulating cheap made in Nigeria exports due to the devalued naira (Ajibefun and Daramola, 2003).

In this regard, devaluation has been argued to be an inefficient policy tool to encourage exports due to globalisation of trade that has increased international trading markets (Reinhart, 1995; Obokoh and Ehiobuche, 2011). In addition, it was suggested that the import elasticity of demand for imported goods for the devaluing country must be greater than one for devaluation to be effective export stimulating instrument (Le and Tran, 1995; Akinlo, 1996; Pham and Nguyen, 1999). Apart from these, a nation's competitive advantage in the international business environment such 
as its resources and infrastructure (Porter, 1990) ought to be considered before applying devaluation as an export encouraging instrument.

In the case of Nigerian, it appears that both the IMF/World Bank and the Nigerian government did not put into consideration the state of the industrial sector and its dependence on imported raw materials for production (Akinlo and Odusola, 2003). This is because after the adoption of the floating exchange rates, there was a general increase in price level which subsequently led to the fall in the purchasing power of Nigerians (Dawson, 1994; Ekpenyong, 2002). The poor purchasing power translated to reduced patronage of domestic manufacturers. Besides, the liberalisation policy precluded the government from the active participation in economic activities which necessitated the commercialisation and privatisation of public parastatals. This prompted the neglect of infrastructures such as electricity, supply of water and good roads which the government had hoped for private investors that never materialised (Lee and Anas, 1992). The lack of interest by private investors in addition to the cuts in budget for the maintenance of these infrastructures led to the deplorable state of infrastructure in Nigeria. The poor state of infrastructure then translated to the self-provision by manufacturing SMEs which in turn adversely affected their costs of operation (Lee and Anas, 1991; Adenikinju, 2005).

\section{Methodology of the Study}

The study used mixed method of data collection and analysis that tapped on the strengths of both quantitative and qualitative approach that incorporated both quantitative (questionnaire survey) and qualitative (semi-structured interview) data (Morgan 1998; Creswell et al, 2003). The primary source of data represented sampled manufacturing SMEs' perspectives of the impact of financial liberalization policy on their businesses. The study then triangulated the primary data collected from both questionnaires and semi-structured interviews sources with the secondary data from the Central Bank of Nigeria (CBN). Statistical Packages for Social Science (SPSS) 16 and return on investment (ROI) model were used as the instruments of analysis.

The decision to apply mixed methods was driven by the research objectives which was informed by the identified research problems and the need to avoid the methodological problems of previous studies as observed by some scholars such as Rodriguez and Rodrik (2000); Agrawal (2004); Winters (2004) and Stiglitz (2000, 2002, 2004). Besides the economic liberalisation policy regarding interest rates, exchange and privatization that precludes the government from direct participation in the provision of infrastructures has had a wide economic impact which makes it necessary to evaluate these economic variables empirically using micro level data from SMEs.

Questionnaires were the research instrument used for the collection of the quantitative primary data administered to 500 manufacturing SMEs, while the qualitative data instrument was the semi-structured interviews administered to 69 of the 100 SMEs that were purposively selected for the semi-structured interview (Ikhide and Yinusa, 1998; McEvoy and Richad, 2006; Ivankova et al, 2006). The secondary data was collected through statistical compilation of panel data from the CBN records and transaction data of the 69 respondents' SMEs to complete the mixed method.

\subsection{Description of Data Collection Instrument}

This section describes the data collection instruments, namely the questionnaires and the semi-structured interviews and the justification for the use of both instruments for the collection of data in this study.

\subsection{Questionnaires}

The questionnaire was divided into seven sections with each section dealing with each variable that was identified by this study as affecting the performance of manufacturing SMEs in Nigeria which the study sets out to explore. The questionnaire sought the following data from sampled firms: characteristics and profile of the firm; their source of finance before and after the implementation of the liberalization policy; their perception of state of infrastructure; the effects of exchange rate deregulation on their business; the effects of interest rates on their operation and if the deregulation of the interest rates helped to ease their accessibility to finance; their perception of the level of technological development in Nigeria and if the level of technological development in Nigeria affected their operation; and their perception of government support and how adequate are the government support to their operation in the liberalized environment of Nigeria.

The questions were followed by a range of options for which the firms had to tick the option that is most appropriate to them and if otherwise they were met to specify. Since it was not possible to get all the information using this method, the study also used a six point Likert scale to measure the perception of the sampled SMEs on certain issues. The likert scale was to ascertain the perception of the respondents' views on the effects of interest rates charged by the informal money lenders. The decision to employ a six point Likert scale was informed by the outcome of the pilot study. During the pilot study, almost all the participants either avoided or gave evasive answers to questions 
that bothered on the effects of the deregulated interest rates and the exchange rates on their business performance respectively.

Apart from these, most of the respondents were unwilling to give specific information on their business, but were happy to give information on general terms about the impact of the interest and exchange rate deregulation on business operation in general (De Vaus, 2002). They also did not want to paint a picture of failing business fortunes because they were skeptical about the information falling into the hands of their competitors. Furthermore, this method was also the only means of eliciting information on those businesses that have gone out of operation within the manufacturing sector and the reasons for their failure at the time of carrying out the survey (Watson and Everett, 1999). It was not possible to locate the owners of those businesses that have gone out of business for their participation in the survey. This is because there is currently no data base of failed businesses in Nigeria where one could get the contact details of the owners of failed businesses. Attempts were made to get this information from the office of the Nigerian Association of Small and Medium Enterprises (NASME) located in Lagos, but we were told they do not have information on failed businesses.

For the purpose of clarity and ease of interpretation, the six point Likert scale of 'strongly agree', 'agree', 'neither agree nor disagree', 'disagree', 'strongly disagree' and 'not applicable' was collapsed into a three-point Likert scale of 'agree', 'disagree' and 'not applicable' by summing the responses that convey similar meaning together (De Vaus, 2002). The 'neither agree nor disagree' was grouped together with 'not applicable' because both options do not affect the outcome of the result as it assumes neutrality. The 'not applicable' option was included to cater for those respondents that have not started their business as at the time economic liberalisation was implemented and wanted to remain neutral or did not want to participate in a particular question in the questionnaire.

\subsubsection{Justification for the use of Questionnaire Survey}

The questionnaires made it possible to cover a large number of manufacturing SMEs and for the findings to be generalisable based on purposive random sampling of the 500 sample size which yielded a response rate of 430 with 369 valid responses. The questionnaires helped to maximize the possibility of the respondents answering the questions in similar manner and to achieve similar results due to the standardized questions. The questionnaires were pre-tested and found to be able to capture the poor performance of the manufacturing SMEs when the data from the pilot questionnaire survey were analysed.

\subsection{Semi-Structured Interviews}

The semi-structured interviews were used to obtain detailed and retrospective changes in the business environment over the last 12 years and how the liberalization policy has affected manufacturing SMEs in Nigeria. The semi-structured interviews also helped in collecting information that was not possible to collect with the questionnaires. The semi-structured interviews contained questions that solicited information about the sales/turnover, profits, operating costs and assets figures of respondents'. It was from this information that the ROIs for the various years were computed and used to carry out the comparison with the interest rates (cost of capital) from the $\mathrm{CBN}$ data.

The interview data for the study was restricted to 12 years because the 12 years period was the most accurate and up to date data that could be obtained from the 50 SMEs out of the 69 SMEs interviewed for this purpose. The initial plan was to obtain transaction data from 1980 to 2006 so as to enable comparison of the performance of respondents before and after economic liberalisation. Unfortunately, only 9 out of the 369 valid respondents were in existence before the liberalisation policy. Even some of the older SMEs did not have accurate or up to date information beyond the 12 years cut-off mark chosen for the analysis. The non availability of data beyond 12 years from the participants was partly the reason for the 12 years cut off mark. A small number/percentage of those firms that were in existence before the liberalisation policy indirectly explains or gives a picture of the rate of survival/survival chances of manufacturing SMEs despite the policy reforms that were aimed at their development.

\subsubsection{Justification for Using Semi-Structured Interviews}

It was useful for the in-depth study of the transaction records of the 69 manufacturing SMEs that participated in this stage of the study because of the individual firms' information that were provided. It was useful in describing complex phenomenon of the inter-play of interest rates, exchange rates, the cost effects of the lack of infrastructure, competition from established manufacturers and SMEs chances of survival under a liberalized economy.

\subsection{Pilot Study}

Prior to the questionnaire survey and semi-structured interview, a pilot survey was conducted on 50 manufacturing SMEs operating in Ibadan, Oyo State of Nigeria in November 2006. All the firms filled out and returned their pilot 
questionnaires with a lot of blanks as some of the questions were not answered by the firms. The reason for undertaken the preliminary pilot survey was to validate and test whether the survey questionnaire designed for the study was properly constructed to capture the information needed to answer the research questions, and achieve the research objectives in view of the theoretical framework of the study. It was at the pilot stage that it was observed that most of the SMEs that participated were not comfortable giving out certain information such as sales, profit and cost figures which were vital for the attainment of the study's objectives.

This observation partly informed the amendments in terms of reframing; reducing the number of questions and the removal of some of the areas most SMEs were not comfortable with. As a result, the decision to use semi-structured interviews to support the questionnaire survey was arrived at. The semi-structured interview enabled us to specifically request information that could not be obtained through the questionnaires. It is pertinent to state that it was the information garnered from the pilot survey that laid the foundations for the development of the mixed method design for the data collection of this study.

\section{Presentation of Results}

The data collected using mixed methods provided the information to support the holistic review of the impact of financial market liberalisation policy on manufacturing SMEs on the backdrop of the cut in public infrastructure budgets.

\subsection{Analysis of the Aggregate of 50 manufacturing SMEs Return on Investment (ROI)}

The aggregate of the ROI of the 50 manufacturing SMEs were used to holistically ascertain how the two independent variable (interest and inflation rates) impact on the ROI of the interviewed SMEs. The ROI is the measure of investment appraisal use to measure the performance of divisional managers in a decentralised organisation where each manager is accountable for investment and profits. Here each of the SMEs taken to be a division independent of each other with regard to investment decisions. The investment decisions were assumed to be made in the best interest of each division for the purpose of making profit and staying in business. The interest rate is very important in the use of ROI as a measure of performance because it is the investors reward for the use of their fund or the cost of capital (COC) pay to the investor for the use of their funds. This is determined by market forces in line with liberalisation with inflation rate floating freely according to market condition.

In computing ROI, the study did not adjust for the depreciation of the naira and inflation since it was using profit and asset figures to compute for ROI from the point of view of the SMEs who would have felt justified continuing in business since their ROI is above cost of capital (interest rate). It is also assumed that depreciation and inflation affected the value of asset and profit of the SMEs in the same way. Although Akinlo (1996) adjusted for depreciation and inflation in order to demonstrate that the high profits posted by manufacturing industries after the introduction of structural adjustment programme (SAP) in Nigeria, which later metamorphosed to liberalisation were due to inflationary effects.

The computed ROI from the asset and profit of interviewed SMEs as shown in table 1 responds negatively to interest rates and inflation. It shows that the higher the interest rate and the inflation rates, the lower the ROI and the lower the interest and inflation rates, the higher the ROI. This trend ironically obeys the law of demand which ordinarily a rational SMEs would have preferred a stable ROI. On the surface the aggregate ROI of the 50 SMEs looks encouraging because it still provide some positive margin of safety (MOS) from the market interest rate with the exception of 1995, 2002 and 2004 when the MOS were negative. The margin of safety within the context of this study is the difference between ROI and interest rate and the level below which SMEs ROI must not fall below so as not to discourage owners of business from continuing in business.

\subsection{Analysis of the Aggregate of 25 SMEs Partly Financed by Owners Funds and Retained Profit}

This section analyses the group of 25 manufacturing SMEs that financed their operations using owners' funds and retained profits from their business over the years. It was gathered during the interview from the SMEs, that they had in the past secured loans from either the informal or formal sector as the report of the questionnaire also indicates, but have liquidated the loans because of the cost of servicing these loans. While some in this group said they tried but could not secure loans and were able to take advantage of suppliers' credit facilities which allows them some period of grace before paying for their raw material purchases without paying interest. Even when they were facing liquidity problems they were able to negotiate extension of payment dates to the suppliers for raw material purchases. 
The computed ROI of the 25 SMEs that financed their operations with owners' funds and retained profits, from their business was used to compare the ROI of the 50 SMEs. The slight difference is in 1995 when the ROI for the 25 SMEs showed a negative value with the 50 SMEs and also in 2002.

\subsection{Analysis of the Aggregate of 25 SMEs Partly Financed by Owners Funds and Loans}

The ROI for this group was also computed using the aggregate assets and aggregate profits posted for each year by the 25 manufacturing SMEs that their operations are partly financed by owners' funds and loans. The difference between the ROI and the interest rates for each year gave the MOS. From the table, it was observed that except for 1997, 1999, 2000 and 2006 years of operation, the computed MOS for this group of SMEs were all negative. The worst years of the MOS were 1995, 2002 and 2004 when the interest rates ranged from 19.47\% to 20.48\%. Apart from inflation and the naira depreciation, the factor that affected these SMEs most is the interest rates. Since they were partly financed by loans or credit facilities which they had to pay interest on every month or annually as the case may be, the cost of operation increased by the financial cost or the cost of borrowing which is the interest rate on the loan facility. This was unlike the first group that were most affected by the inflation rate and depreciation of the naira. In other words, this group of SMEs that financed their operation with owners' funds and loans were worse hit by the deregulation of interest rates and the depreciation of the naira.

It was observed from the computed ROI of the 50 manufacturing SMEs and the ROIs computed when the 50 SMEs were split into two groups that the first 25 SMEs ROI does not give an impressive performance. For the fact that the 25 SMEs that financed their operation with owners' funds and retained profits show a better performance than the other group that their operations were partly financed by owners' funds and loans does not put them above market and environmental risk. The MOS as can be seen in table 2 are still too small to cater for dividend assuming these businesses were to pay dividends to shareholders.

\subsection{Discussion of Results}

The results of the analysis of this study revealed a lot of contradictions with the predictions of the theories behind financial market liberalisation in Nigeria and the envisaged policy outcomes. These contradictions include:

The interest rate deregulation negatively affected the performance of sampled SMEs. This was confirmed by the survey and operational costs of SMEs. A critical look at the interest rates differentials between Nigeria and the countries in the table 4 clearly shows that manufacturing SMEs in Nigeria stand no chance of competition with manufacturers from those countries. Their cost of finance is very low compared to that of SMEs in Nigeria. From the survey, the respondents that still had loan obligations stated they are finding it difficult to met the interest payments.

The deregulation of exchange rates did not discourage the importation and consumption of imported finished goods in Nigeria instead it increased the cost of financing raw materials from both local and international sources. This also significantly affected SMEs performance and is linked to one of the reasons why some SMEs changed their business objectives from manufacturing to retail business. This is because most of the sampled SMEs stated that it was cheaper to import than to manufacture the same product in Nigeria.

The financial market liberalisation did not solve the problem of access to finance for SMEs despite the increase in the number of financial institutions. It was observed from the analysis that the number of SMEs that had access to formal finance decreased after the implementation of the liberalisation policy. In fact the high interest rates was the reason given for the lack of interest in seeking formal or informal finance for their operations as most of the participants in the semi-structured interviews believed that it was better to rely on their retained profits for their operations. This they claimed was a better means of cutting down their operational costs.

Some economic constraints such as lack of access to modern manufacturing equipment due to low level of technology in Nigeria, absence of infrastructure and special SMEs funds faced by SMEs before liberalisation still persists after the implementation of the policy. The problem of infrastructure was even more compounded with the cut in the budgets for the provision of public utilities by the government. This is evidenced by the present deplorable state of infrastructure in Nigeria. The deplorable state of infrastructure has also significantly affected SMEs costs and their competitiveness because they had to embark on self-provision of some of these infrastructures. Furthermore, $85 \%$ of sampled SMEs reported that they were yet to benefit from the promised government support for SMEs due to corruption and favouritism on the part of government officials in charge of the programmes.

\section{Concluding Remarks}

Base on the questionnaire survey and the semi-structured interviews results, this study concludes that financial market liberalisation policy that was meant to encourage the private sector hence manufacturing SMEs negatively impacted on their performance and survival in Nigeria. In other words, the policy partly contributed to the failures of 
most manufacturing SMEs in Nigeria contrary to the policy objective of improved SMEs opportunities and access to finance. Instead of the competitive free-market rates to attract funds for investment as postulated by McKinnon \& Shaw (1973), it became an obstacle that partly hinders the survival of manufacturing SMEs. The result of the study is further strengthened by the current global financial crisis and the call for regulation of the financial markets by some financial analysts in line with Stiglitz $(1994 ; 2004)$ market failure rationale for government intervention.

\subsection{Implication}

The efficient allocation of financial resources and proper functioning of the financial market cannot be complete without government intervention. For the policy to have meaningful impact on private sector growth in Nigeria and other SSA countries, the government need to re-adjust and review the present policy of unregulated interest rates and floating exchange rates. In addition to taking appropriate steps in solving the infrastructure problems manufacturers faced by the increase in budgetary allocation to the maintenance and expansion of infrastructure in Nigeria.

\section{References}

Adenikinju, A. (2005). Analysis of the Cost of Infrastructure Failures in a Developing Economy: The case of the Electricity Sector in Nigeria. AERC Research Paper 148, African Economic Research Consortium, Nairobi.

Adedipe, B. (2006). Capital Account Liberalisation: What Options for Developing Countries? Central Bank of Nigeria Economic and Financial Review, 44(4), 63-87.

Agrawal, P. (2004). Interest Rates and Investment in East Asia: An Empirical Evaluation of Various Financial Liberalization Hypotheses. Journal of Development Studies, 40(3), 142-173. http://dx.doi.org/10.1080/0022038042000213238

Ajibefun, I. A., \& Daramola, A. G. (2003). Efficiency of Microenterprises in Nigerian Economy. AERC Research Paper 134, African Economic Research Consortium, Nairobi.

Akinlo, A. E. (1996). The Impact of Adjustment Programme on Manufacturing Industries in Nigeria, 1986 1991: A Sample Study. African Development Review, 16, 73-93.

Akinlo, A. E., \& Odusola, A. F. (2003). Assessing the Impact of Nigeria's Naira Depreciation on Output and Inflation. Applied Economics, 36(6), 691-703. http://dx.doi.org/10.1080/0003684032000056823

Amin, M., R. \& Banerjee, S. (2007). Constraints and Contingencies of the Small Business: A Comparative Perspective. International Business \& Economics Research Journal, 6(9), 59-66.

Ayadi O. F., \& Hyman, L. (2006). Financial Liberalization and Price Rigidity in the Nigerian Banking System. Managerial Finance, 32(7), 557-568. http://dx.doi.org/10.1108/03074350610671557

Bello, W. (2007). The Post-Washington Dissensus. Foreign Policy in Focus. [online] Available: http://www.fpif.org. (July 21, 2007)

Berry, A. (2002). The Role of the Small and Medium Enterprise Sector in Latin America and Similar Developing Economies. Seton Hall Journal of Diplomacy and International Relations, 104-119.

Creswell, J. W., Plano Clark, V. L., Gutmann, M., \& Hanson, W. (2003). Advanced Mixed Methods Research Designs. Handbook On Mixed Methods In The Behavioral And Social Sciences, eds. A. Tashakkori and C. Teddlie, 209-40. Thousand Oaks, CA: Sage.

Dawson, J. (1994). Responses to Adjustment - the Marginalization of Small Enterprises in Nigeria. Small Enterprise Development, 5(2), 18-24. http://dx.doi.org/10.3362/0957-1329.1994.015

De Vaus, D. (2002). Surveys in Social Research. Fifth Edition Routledge. London: Taylor and Francis Group.

Ebhodaghe, J. U. (1996). Distress management and prevention strategies for the Nigerian banking system. Nigeria Deposit Insurance Company Quarterly.

Ekpenyong, D. B. (2002). Performance of Small Scale Enterprises in Nigeria during the Structural Adjustment Programme Implementation: Survey Findings. Journal of Financial Management \& Analysis, 15(1), 38-50.

Emeseh, E., Ako, R., Okonmah, P., \& Obokoh, L. O. (2010). Corporations, CSR and Self Regulation: What Lessons from the Global Financial Crisis. German Law Journal, 11(2), 230-258.

Fry, M. J. (1988). Money, Interest, and Banking in Economic Development. Baltimore, Johns Hopkins University Press. 
Hellmann, T. F., Murdock K. C., \& Stiglitz, J. E. (2000). Liberalization, Moral Hazard in Banking, and Prudential Regulation: Are Capital Requirements Enough? The American Economic Review, 90(1), 147-165. http://dx.doi.org/10.1257/aer.90.1.147

Henry, P. B. (2003). Capital Account Liberalisation, the Cost of Capital and Economic Growth. The American Economic Review, 93(2), 91-96. http://dx.doi.org/10.1257/000282803321946868.

Hübler, O., Menkhoff, L. \& Suwanaporn, C. (2008). Financial Liberalisation in Emerging Markets: How Does Bank Lending Change? The World Economy, 393-415.

Ikhide, S. I. \& Alawode, A. A. (2001). Financial Sector reforms, Macroeconomic Instability and the order of Economic Liberalisation: The Evidence from Nigeria. AERC Research Paper 112. African Economic Research Consortium, Nairobi,

Ikhide, S. I., \& Yinusa, D. O. (1998). The Impact of Financial Liberalisation on the Finance of Small and Medium Scale Enterprises in Nigeria Research report 12. Ibadan: Development Policy Centre,

Ikpeze, N. I., Soludo, C. C., \& Elekwa, N .N. (2004). The Political Economy of the Policy Process, Policy choice and Implementation. in Soludo, C. C., Ogbu, O. and Chang, H. (eds), The Politics of Trade and Industrial Policy in Africa, Forced Consensus?, Canada: African World Press.

Ivankova, N. V., Creswell, J. W., \& Stick, S. L. (2006). Using Mixed-Methods Sequential Explanatory Design: From Theory to Practice. Field Methods, 118(1), 3-20. http://dx.doi.org/10.1177/1525822X05282260

Khatkhate, D. R., (1988). Assessing the impact of interest rates in less developed Countries. World Development, 16(5), 577-588. http://dx.doi.org/10.1016/0305-750X(88)90187-8

Kyaruzi, I. S. (2006). Business Incubation and Clustering in Tanzania: Local Economic Growth, Entrepreneurship and Business Support Policies. PhD thesis submitted to the University of Birmingham, United Kingdom.

Larrain, F. (1989). Debt, Adjustment and Recovery: Latin America's Prospects for Growth and Development. Oxford:Basil Blackwell,

Le, V. D., \& T. H. (1995). On Devaluation and the Possibility to Devalue the Currency of Our Country. Journal of Economic Studies, 3(205), 11-29.

Lee, K. S., \& Anas, A. (1991). Manufacturers' Responses to Infrastructure Deficiencies in Nigeria: Private Alternatives and Policy Options. In A. Chibber and S. Fischer, (eds.), Economic Reform in Sub-Saharan Africa, A World Bank Symposium.

Lee, K. S., Anas A. (1992). Costs of Deficient Infrastructure: The Case of Nigerian Manufacturing. Urban Studies, 29(7), 1071-1092(22).

Madill, J. J., Allan A. R, \& George H. H. (2006). Women Entrepreneurs: Debt Financing and Banking Relationship. Journal of Small Business and Entrepreneurship, 19(2) 121-142.

Mailafia, O. (2006). Capital Account Liberalisation: Reflections on Theory and policy. Central Bank of Nigeria Economic and Financial Review, 44(4), 11-29.

Mambula, C. (2002). Perceptions of SME Growth Constraints in Nigeria. Journal of Small Business Management, 40(1), 58-65. http://dx.doi.org/10.1111/1540-627X.00039

McEvoy, P., \& Richards, D. (2006). A Critical Realist Rationale for using a Combination of Quantitative and Qualitative Methods. Journal of Research in Nursing, 11(1), 66-78. http://dx.doi.org/10.1177/17444987106060192

Mckinnon, R. I. (1973). Money and Capital in Economic Development. Brookings Institution. Washington D.C

Morgan, D. (1998). Practical Strategies for Combining Qualitative and Quantitative Methods: Applications to Health Research. Qualitative Health Research, 8, 362-76. http://dx.doi.org/10.1177/104973239800800307

Musa, Y.W., \& Danjuma, D. M. (2007). Small and medium scale enterprises: A veritable tool for sustainable job creation in Nigeria. Journal of Business and Public Policy, 1, 1-25.

Mussa, M. (2000). Factors Driving Global Economic Integration: Opportunities and Challenges. Kansas City, Missouri.

Noorbakhsh, F., \& Paloni, A. (2001). Structural Adjustment and Growth in Sub-Saharan Africa: The Importance of Complying with Conditionality. Economic Development and Cultural Change, 49(3), 479-509. http://dx.doi.org/10.1086/452512

Nwankwo, S., \& Richards, D. (2001). Privatization: the myth off free market orthodoxy in Sub-Saharan Africa. International Journal of Public Sector Management, 14(2), 165-179. http://dx.doi.org/10.1108/09513550110387453 
Obadan, M.I. (2006). Globalization of Finance and the Challenge of National Financial Sector Development. Journal of Asian Economics, 17(2), 316-332. http://dx.doi.org/10.1016/j.asieco.2005.11.002

Obokoh, L. O. (2008a). Small and Medium Sized Enterprises Development under Trade Liberalisation: A Survey of Nigerian Experience. International Journal of Business and Management, 3(12), 92-101.

Obokoh, L. O. (2008b). Capital Account Liberalisation: Survey of SMEs Experience in Nigeria. $31^{\text {st }}$ Institute for Small Business and Entrepreneurship Conference, $5^{\text {th }}-7^{\text {th }}$ November, 2008, Belfast Northern Ireland.

Obokoh, L. O., \& Ehiobuche, C. (2011). Globalisation of Finance: Analysis of the Impact of Exchange Rate Deregulation on Small and Medium Sized Enterprises Development in Nigeria. $56^{\text {th }}$ International Council for Small Business (ICSB) World Conference in Stockholm, Sweden, June 15-18.

Okome, M. O. (1999). State and civil society in Nigeria in the era of structural adjustment program. [online] Available: http://www.icaap.org/iuicode?101.1.1.9. (November 17, 2005)

Olukoshi, A. (1996). Economic Crisis, Structural Adjustment and the Coping Strategies of Manufacturers in Kano, Nigeria. United Nations Research Institute for Social Development Discussion Paper 77.

Owualah, S.I., \& Obokoh, L. O. (2008). Tackling Youth Restiveness in the Niger Delta Region of Nigeria through Entrepreneurship. Journal of Enterprising Communities: People and Places in the Global Economy, 2(2), 168-179. http://dx.doi.org/10.1108/17506200810879989

Pham, C. Q., \& Nguyen, V. C. (1999). The Impact of Exchange Rate Changes on Balance of Payments in Vietnam Since1989. Journal of Economics Studies, 12(259), 3-21.

Porter, M. (1990). The Competitive Advantage of Nations, the Free Press, A Division of Macmillian, Inc. New York, NY.

Prasad, E., Rogoff, K.,Wei, S., \& Kose M. A. (2003). Effects of Financial Globalization on Developing Countries: Some Empirical Evidence. Mimeograph, International Monetary Fund. Reinhart, C.M. (1995). Devaluation, Relative Prices, and International Trade Evidence from Developing Countries. International Monetary Fund, 42(2), 290-312.

Rodríguez, F., \& Rodrik, D. (2000). Trade Policy and Economic Growth: A Sceptic's Guide to the Cross National Evidence. CEPR Discussion Paper No. 2143. London, Centre for Economic Policy Research.

Sachs, J. D., \& Warner, A. (1995). Economic Reform and the Process of Global Integration. Brookings Papers on Economic Activity, 1, 1. http://dx.doi.org/10.2307/2534573

Schneider, B. (2000). Conference Report on Capital Account Liberalization: A Developing Country Perspective. Overseas Development Institute, London, June 21, 2000.

Shaw, E. (1973). Financial Deepening in Economic Development, New York: Oxford University Press. Siddiki, J. U. (2000). Demand for Money in Bangladesh: a Co-integration Analysis. Applied Economics, 32(15), 1977-1984(8).

Stiglitz, J. E. (1998). More Instruments and Broader Goals: Moving towards the Post-Washington Consensus. United Nations University. World Institute for Development Economics Research, Helsinki.

Stiglitz, J. E, Ocampo, J. A., Spiegel, S., Ffrench-Davis, R., \& Nayyar, D. (2006). Stability with Growth: Macroeconomics, Liberalisation, and Development. New York: Oxford University Press.

Stiglitz, J. E. (2000). Capital Market Liberalisation, Economic Growth, and Stability. World Development, 28(6), 1075-1086. http://dx.doi.org/10.1016/S0305-750X(00)00006-1

Stiglitz, J. E. (2004). Capital-Market Liberalisation, Globalisation, and the IMF. Oxford Review of Economic Policy, 20(1), 57-71. http://dx.doi.org/10.1093/oxrep/grh004

Stiglitz, J. E., (2002). Capital Market Liberalization and Exchange Rates Regimes: Risk without Reward.

The Annals of the American Academy, 579, 219- 248.

Stiglitz, J.E., \& Weiss, A. (1981). Credit Rationing in Markets with Imperfect Information. The American Economic Review, 71(3), 393-410.

Taylor, L. (1983). Structuralist Macroeconomics: Applicable Models for the Third World. New York: Basic Books.

Van Wijnbergen, S. (1982). Stagflationary Effects of Monetary Stabilization Policies: A Quantitative Analysis of South Korea. Journal of Development Economics, 10(2), 133-69. http://dx.doi.org/10.1016/0304-3878(82)90014-1

Van Wijnbergen, S. (1985). Macro-economic effects of changes in bank interest rates: Simulation results 
for South Korea. Journal of Development Economics, 18(2-3), 541-554. http://dx.doi.org/10.1016/0304-3878(85)90072-0

Watson, J., \& Everett, J. (1999). Small Business Failure Rates: Choice of Definition and Industry Effects. International Small Business Journal, 17(2), 31-48. http://dx.doi.org/10.1177/0266242699172002

Winters, L. A. (2004). Trade Liberalisation and Economic Performance: An Overview, Economic Journal, 114, 4-21. http://dx.doi.org/10.1111/j.0013-0133.2004.00185.x

Zhang, X. (2006). Financial Market Governance in Developing Countries: Getting Political Underpinnings Right. Journal of Developing Societies, 22(2), 169-196. http://dx.doi.org/10.1177/0169796X06065801

Table 1. Aggregate Asset, Profits, Computed ROI of 50 Sampled SMEs, Interest Rates, Inflation Rates, Naira Exchange Rate to One US\$ and the Rate of Naira Depreciation to One US\$

\begin{tabular}{|c|c|l|l|l|l|l|l|l|}
\hline Year & $\begin{array}{l}\text { Asset in } \\
\text { Naira } \\
\text { N'000) }\end{array}$ & $\begin{array}{l}\text { Profit in } \\
\text { Naira } \\
\text { (N'000) }\end{array}$ & $\begin{array}{l}\text { Return on } \\
\text { Investment (ROI) } \\
\text { (in \%) }\end{array}$ & $\begin{array}{l}\text { Interest } \\
\text { Rate } \\
\text { (COC) }\end{array}$ & $\begin{array}{l}\text { MOS } \\
\text { (in \%) }\end{array}$ & $\begin{array}{l}\text { Inflation } \\
\text { Rate }\end{array}$ & $\begin{array}{l}\text { Naira } \\
\text { Exchange Rate } \\
\text { to One US\$ }\end{array}$ & $\begin{array}{l}\text { Rate of Naira } \\
\text { One US\$ }\end{array}$ \\
\hline 1994 & Nil & Nil & Nil & 21.00 & Nil & 57.00 & 21.87 & $(0.82)$ \\
\hline 1995 & 112292 & 20212.56 & 18.0 & 20.18 & $(2.18)$ & 73.10 & 81.02 & 270.46 \\
\hline 1996 & 168438 & 37056.36 & 22.0 & 19.74 & 2.26 & 29.10 & 81.25 & 0.28 \\
\hline 1997 & 286345 & 71586.25 & 25.0 & 13.54 & 11.75 & 8.50 & 81.65 & 0.50 \\
\hline 1998 & 314665 & 61359.68 & 19.5 & 18.29 & 1.21 & 10.00 & 83.81 & 2.65 \\
\hline 1999 & 349628 & 82512.21 & 23.6 & 21.32 & 2.28 & 6.60 & 92.34 & 10.18 \\
\hline 2000 & 371945 & 76620.67 & 20.6 & 17.98 & 2.62 & 6.90 & 100.8 & 9.16 \\
\hline 2001 & 383449 & 71704.96 & 18.7 & 18.29 & 0.41 & 18.90 & 111.7 & 10.81 \\
\hline 2002 & 473394 & 79056.80 & 16.7 & 20.48 & $(3.78)$ & 12.90 & 126.26 & 13.03 \\
\hline 2003 & 537948 & 123728.04 & 23.0 & 21.16 & 1.81 & 14.00 & 134.04 & 6.16 \\
\hline 2004 & 645537 & 116196.66 & 18.0 & 19.47 & $(1.47)$ & 19.40 & 134.73 & 0.52 \\
\hline 2005 & 694755 & 154930.37 & 22.3 & 20.00 & 2.30 & 17.90 & 145.82 & 8.23 \\
\hline 2006 & 771951 & 186040.19 & 24.1 & 18.70 & 5.40 & 12.60 & 148.46 & 1.81 \\
\hline
\end{tabular}

Source: CBN Statistical Bulletin 2006 and computation from Semi-structured interview data

Table 2. Showing Aggregate Asset, Profits, Computed ROI of 25 Sampled SMEs*, Interest Rates, Inflation Rates, Naira Exchange Rate to One US\$ and the Rate of Naira Depreciation to One US\$

\begin{tabular}{|c|c|c|c|c|c|c|c|c|}
\hline Year & $\begin{array}{c}\text { Asset in } \\
\text { Naira } \\
\text { (N'000) }\end{array}$ & $\begin{array}{c}\text { Profit in } \\
\text { Naira } \\
\text { (N'000) }\end{array}$ & $\begin{array}{c}\text { Return on } \\
\text { Investment } \\
\text { (ROI) } \\
\text { (in \%) }\end{array}$ & $\begin{array}{c}\text { Interest } \\
\text { Rate } \\
\text { (COB) }\end{array}$ & $\begin{array}{c}\text { (ROI)-(COB)= } \\
\text { MOS } \\
\text { (in \%) }\end{array}$ & $\begin{array}{c}\text { Inflation } \\
\text { Rate }\end{array}$ & $\begin{array}{c}\text { Naira } \\
\text { Exchange Rate } \\
\text { to One US\$ }\end{array}$ & $\begin{array}{c}\text { Rate of Naira } \\
\text { Depreciation to } \\
\text { One US\$ }\end{array}$ \\
\hline 1994 & Nil & Nil & Nil & 21.00 & Nil & 57.00 & 21.87 & $(0.82)$ \\
\hline 1995 & 67375.20 & 13475.04 & 20 & 20.18 & $(0.18)$ & 73.10 & 81.02 & 270.46 \\
\hline 1996 & 104431.60 & 24541.42 & 23.5 & 19.74 & 3.76 & 29.10 & 81.25 & 0.28 \\
\hline 1997 & 183260.80 & 49480.42 & 27 & 13.54 & 13.46 & 8.50 & 81.65 & 0.50 \\
\hline 1998 & 191945.70 & 40308.59 & 21 & 18.29 & 2.71 & 10.00 & 83.81 & 2.65 \\
\hline 1999 & 216769.40 & 52024.65 & 24 & 21.32 & 2.68 & 6.60 & 92.34 & 10.18 \\
\hline 2000 & 230605.90 & 49810.87 & 21.6 & 17.98 & 3.62 & 6.90 & 100.8 & 9.16 \\
\hline 2001 & 239676.40 & 47935.29 & 20 & 18.29 & 1.71 & 18.90 & 111.7 & 10.81 \\
\hline 2002 & 284036.40 & 51694.62 & 18.2 & 20.48 & $(2.28)$ & 12.90 & 126.26 & 13.03 \\
\hline 2003 & 344286.70 & 86071.68 & 25 & 21.16 & 3.84 & 14.00 & 134.04 & 6.16 \\
\hline 2004 & 413143.70 & 86760.17 & 21 & 19.47 & 1.53 & 19.40 & 134.73 & 0.52 \\
\hline 2005 & 437695.70 & 105047.00 & 24 & 20.00 & 4.00 & 17.90 & 145.82 & 8.23 \\
\hline 2006 & 501768.20 & 130459.70 & 26 & 18.70 & 7.3 & 12.60 & 148.46 & 1.81 \\
\hline
\end{tabular}

Source: CBN Statistical Bulletin 2006 and computation from interview data

*25 from the 50 SMEs that partly finance their operation from owners' funds and retained profits 
Table 3. Showing Aggregate Asset, Profits, Computed ROI of 25 Sampled SMEs*, Interest Rates, Inflation Rates, Naira Exchange Rate to One US\$ and the Rate of Naira Depreciation to One US\$

\begin{tabular}{|c|c|l|l|l|l|l|l|l|}
\hline Year & $\begin{array}{l}\text { Asset in Naira } \\
\text { (N'000) }\end{array}$ & $\begin{array}{l}\text { Profit in } \\
\text { Naira } \\
\text { (N'000) }\end{array}$ & $\begin{array}{l}\text { Return on } \\
\text { Investment } \\
\text { (ROI) } \\
\text { (in \%) }\end{array}$ & $\begin{array}{l}\text { Interest } \\
\text { Rate } \\
\text { (COB) }\end{array}$ & $\begin{array}{l}\text { MOS } \\
\text { (ROI)-(COB) }) \\
\text { (in \%) }\end{array}$ & $\begin{array}{l}\text { Inflation } \\
\text { Rate }\end{array}$ & $\begin{array}{l}\text { Naira Exchange } \\
\text { Rate to One } \\
\text { US\$ }\end{array}$ & $\begin{array}{l}\text { Rate of Naira } \\
\text { Depreciation } \\
\text { to One US\$ }\end{array}$ \\
\hline 1994 & Nil & Nil & Nil & 21.00 & Nil & 57.00 & 21.87 & $(0.82)$ \\
\hline 1995 & 44916.80 & 6737.52 & 15 & 20.18 & $(5.18)$ & 73.10 & 81.02 & 270.46 \\
\hline 1996 & 64006.44 & 12514.94 & 19.55 & 19.74 & $(0.74)$ & 29.10 & 81.25 & 0.28 \\
\hline 1997 & 103084.20 & 22105.83 & 21.44 & 13.54 & 7.90 & 8.50 & 81.65 & 0.50 \\
\hline 1998 & 122719.40 & 21051.09 & 17.15 & 18.29 & $(1.14)$ & 10.00 & 83.81 & 2.65 \\
\hline 1999 & 132858.60 & 30487.56 & 22.95 & 21.32 & 1.63 & 6.60 & 92.34 & 10.18 \\
\hline 2000 & 141339.10 & 26809.80 & 18.97 & 17.98 & 0.99 & 6.90 & 100.8 & 9.16 \\
\hline 2001 & 153739.00 & 23769.67 & 15.46 & 18.29 & $(2.83)$ & 18.90 & 111.7 & 10.81 \\
\hline 2002 & 189357.60 & 27362.18 & 14.45 & 20.48 & $(6.03)$ & 12.90 & 126.26 & 13.03 \\
\hline 2003 & 193661.30 & 37656.36 & 19.44 & 21.16 & $(1.66)$ & 14.00 & 134.04 & 6.16 \\
\hline 2004 & 232393.30 & 29436.49 & 12.67 & 19.47 & $(6.80)$ & 19.40 & 134.73 & 0.52 \\
\hline 2005 & 257059.40 & 49883.41 & 19.41 & 20.00 & $(0.59)$ & 17.90 & 145.82 & 8.23 \\
\hline 2006 & 270182.90 & 55580.47 & 20.57 & 18.70 & 1.87 & 12.60 & 148.46 & 1.81 \\
\hline
\end{tabular}

Source: CBN Statistical Bulletin 2006 and computation from interview data

**25 from the 50 SMEs that partly finance their operation from owners' funds and loans

Table 4. Interest Rate Differentials (\%)

\begin{tabular}{|c|c|c|c|c|c|}
\hline Year & Nigeria & Europe & USA & Japan & United Kingdom \\
\hline 2000 & 17.98 & 4.9 & 6.4 & 0.5 & 5.9 \\
\hline 2001 & 18.29 & 3.2 & 2.4 & 0.1 & 4.1 \\
\hline 2002 & 20.48 & 2.2 & 1.6 & 0.0 & 4.1 \\
\hline 2003 & 21.16 & 2.2 & 1.3 & 0.0 & 4.4 \\
\hline 2004 & 19.47 & 2.2 & 2.9 & 0.0 & 4.9 \\
\hline 2005 & 20.00 & 2.7 & 4.8 & 0.1 & 4.7 \\
\hline 2006 & 18.70 & 3.7 & 5.4 & 0.5 & 5.3 \\
\hline
\end{tabular}

Source: Extracted from Adedipe (2006) and CBN various issue 